\title{
Komunikasi Efektif untuk Perubahan Organisasi \\ (Komentar tentang Era Perubahan UNP Menuju World Class University)
}

\author{
Indah Ulthari', Alim Harun Pamungkas \\ ${ }^{1}$ Anggota Unit Kegiatan Komunikasi dan Penyiaran Kampus (UK-KPK), Mahasiswa S1 Jurusan Pendidikan Luar Sekolah Fakultas IImu \\ Pendidikan Universitas Negeri Padang \\ ${ }^{2}$ Dosen Jurusan Pendidikan Luar Sekolah Fakultas IImu Pendidikan Universitas Negeri Padang
}

Sejak diraihnya akreditasi A dari Badan Akareditasi Nasional Perguruan Tinggi (BANPT) oleh Universitas Negeri Padang (UNP), maka peluang menuju World Class University (WCU) semakin terbuka. Harapan perubahan setelah dua tahun waktu berjalan terus secara berkesinambungan menjadi bahan kajian dan telaah secara bersama dari lintas disiplin. Artikel ini merupakan komentar terhadap situasi perubahan yang sedang dicapai.

\section{Pendekatan Teoritik}

Perubahan organisasi merupakan salah satu fokus dalam studi manajemen. Namun demikian, perubahan organisasi yang dikaji berdasar pada studi manajemen ternyata belum tentu menghasilkan perubahan seperti yang diharapkan. Salah satu hasil penelitian yang dikutip adalah dari Bibler pada tahun 1989 yang dipublikasikan melalui sebuah karya berjudul "The Arthur Young management guide to mergers and acquisitions" yang selanjutnya disusul oleh Beer \& Nohria pada tahun 2000 melalui karyanya berjudul "Breaking the code of change". Menurutnya, dari sepuluh upaya perubahan organsasi yang dilakukan, ternyata tidak satu pun yang berhasil. Tingkat kegagalan perubahan organisasi rata-rata mencapai 80-90 persen. Artinya, kondisi tersebut menunjukkan bahwa separuh dari upaya perubahan organisasi tidak memperoleh hasil sesuai yang diharapkan. Salah satu sebab utama yang disinyalir adalah terjadinya kegagalan pada tingkat komunikasi organisasi.

Pengelolaan komunikasi yang buruk menghasilkan resistensi terhadap perubahan dan justru memperbesar aspek negatif dari perubahan yang diinginkan. Menurut DiFonzo \& Bordia melalui karyanya yang dipublikasikan melalui Human Resource Management Journal (1998) menyatakan bahwa komunikasi merupakan sesuatu yang penting dalam target implementasi keefektifan perubahan organisasi.
Hasil penelitian Zhang \& Agarwal (2009) berjudul "The mediating roles of organizational justice on the relationships between HR practices and workplace outcomes: An investigation in China" menunjukkan bahwa perubahan organisasi dan proses komunikasi adalah sebuah proses yang terkait erat satu sama lain. Komunikasi dalam organisasi memiliki hubungan dengan komitmen organisasi, kinerja, perilaku anggota organisasi, dan kepuasan kerja. Sebaliknya, kegagalan komunikasi dalam organisasi dapat menghasilkan stress, ketidakpuasan, ketidakpercayaan, dan penurunan komitmen terhadap organisasi.

\section{Komunikasi Organisasi UNP Menuju WCU}

Komunikasi tentang target UNP menuju WCU sudah semestinya menjadi sesuatu yang penuh makna bagi seluruh sivitas akademika UNP. Komunikasi yang penuh makna berguna untuk menginformasikan dan mendidik seluruh sivitas akademika UNP pada semua level, serta untuk memotivasi mereka dalam memberikan dukungan terhadap strategi perubahan menuju WCU.

Terdapat dua tujuan komunikasi yang perlu ditetapkan dalam perubahan menuju WCU. Diadopsi dari De Ridder (2003), sebagai berikut. Pertama, untuk menginformasikan tentang tugastugas bersama seluruh sivitas akademika UNP serta kebijakan WCU yang dicanangkan. Prinsip komunikasinya adalah dari pimpinan di level universitas kepada mahasiswa, dosen, karyawan, dan masyarakat yang beraviliasi dengan UNP. Komunikasi yang dibangun tentu haruslah melalui komunikasi internal di arus bawah. Kedua, untuk membangun kesadaran sebagai sebuah keluarga, yaitu keluarga besar UNP.

Selain itu, sikap positif dari seluruh sivitas akademika UNP untuk berubah sangat menentukan keberhasilan perubahan organisasi yang diinginkan. Resistensi terhadap perubahan UNP menuju WCU merupakan salah satu hambatan terbesar yang harus diatasi. Sesuai 
dengan pernyataan Elving \& Hansma (2008), komunikasi yang penuh makna membutuhkan pemahaman dan penghargaan tentang rencana perubahan UNP yang diinginkan.

Keberhasilan perubahan UNP menuju WCU dan durasi bertahannya situasi perubahan yang diinginkan tersebut, sangat bergantung kepada keterampilan komunikasi dan informasi dari lini pimpinan pada level universitas yang diterima oleh sivitas akademika UNP di semua level. Namun demikian, tentu upaya perubahan ini bukanlah sesuatu yang mudah untuk dilakukan. Karena perubahan tidak sekadar tentang distribusi informasi yang sampai ke level paling bawah UNP, namun juga tentang kontribusi sivitas akademika UNP secara merata di semua level (Bennebroek-Gravenhorst et al., 2006).

Terdapat enam hal yang secara teoritik direkomendasikan oleh Elving (2005) untuk dapat dikaitkan dengan praksis komunikasi dalam target perubahan UNP menuju era WCU. Pertama, rendahnya tingkat resistensi terhadap perubahan atau tingginya tingkat kesiapan untuk perubahan organisasi. Kedua, komunikasi intensif diperlukan untuk menginformasikan kepada anggota organisasi tentang dampak perubahan terhadap jenis tugas dan tanggung jawab baru dalam organisasi. Ketiga, komunikasi harus digunakan untuk menciptakan situasi kekeluargaan yang dapat mewujudkan situasi meningkatnya komitmen dan kepercayaan terhadap organisasi dan strategi pengelolaannya. Keempat, antisipasi terhadap munculnya kekhawatiran atau analisis negatif anggota terhadap target perubahan organisasi. Kelima, memperhatikan efek perampingan struktur dan pembagian peran yang mungkin saja muncul sebagai akibat perubahan organisasi. Keenam, komunikasi tentang perubahan organisasi di semua level dapat membantu dalam memahami situasi kekhawatiran dalam pelaksanaan tugas dan tanggung jawab organisasi.

\section{Tujuan Komunikasi untuk Perubahan UNP Menuju WCU}

Komunikasi yang dilakukan dalam target perubahan UNP menuju WCU tentu difokuskan pada upaya untuk mengatasi permasalahan yang dihadapi oleh seluruh sivitas akademika UNP dan untuk memberikan sentuhan yang manusiawi di dalam pengelolaan kelembagaan perguruan tinggi. Oleh karena itu, muatan (konten) dari komunikasi perlu diperhatikan. Konten dari tujuan komunikasi yang dilakukan UNP menuju WCU setidaknya telah meliputi beberapa orientasi berikut: (1) penyebaran visi baru; (2) mengurangi ketidakpastian terhadap ancaman kegagalan; (3) mendapatkan simpati dan komitmen sivitas; (4) melibatkan sivitas dengan mencari masukan mereka terhadap konten dan proses perubahan yang telah diupayakan; (5) mengatasi hambatan yang mungkin dihadapi menuju target perubahan; dan (6) keberanian dalam menantang kondisi 'status quo' yang ada.

Beberapa saran tentang tujuan komunikasi yang dilakukan selama pengelolaan perubahan UNP menuju WCU, dijelaskan berikut.

Pertama, kemampuan lembaga dalam menjawab kebutuhan. Disesuaikan dengan pendapat Dolphin (2005), komunikasi yang diolah dalam target perubahan UNP menuju WCU haruslah menitikberatkan kepada informasi-informasi penting seperti: gagasan mutakhir dari perubahan yang diusung dan motivasi baru yang ditujukan kepada seluruh sivitas akademika UNP. Komunikasi yang baik secara kontekstual berarti bahwa seluruh mahasiswa, dosen, karyawan dan masyarakat sekitar UNP telah memahami adanya kebutuhan mengenai perubahan, bentuk perubahan yang diinginkan, dan bagaimana perubahan tersebut memberi pengaruh secara komunal bagi kelembagaan UNP dan pengaruh secara personal bagi mahasiswa, dosen, karyawan dan masyarakat di sekitar UNP.

Kedua, kemampuan lembaga dalam menciptakan rasa kekeluargaan. Komunikasi organisasi yang harus ditingkatkan adalah pembentukan identitas bersama. Pandangan tentang rasa komunitas bersama dikutip dari De Ridder (2003), kontekstualisasinya adalah bahwa identitas bersama sebagai satu keluarga UNP penting bagi terbangunnya susasana perubahan. Kondisi ini akan sangat membantu dalam lahirnya identitas kelompok dan semangat sebagai satu keluarga besar UNP yang bergerak menuju perubahan. Komunikasi untuk menciptakan rasa kekeluargaan dalam organisasi dapat diamati dari indikasi komitmen kerja karyawan, karya dosen, partisipasi mahasiswa dalam bidang akademik dan non akademik (organisasi kemahasiswaan) dan kontribusi masyarakat sekitar UNP yang memahami perubahan menuju target WCU (Elving, 2005). 
Ketiga, kemampuan lembaga dalam membangun kepercayaan sivitas akademika UNP. Perspektif yang dominan digunakan oleh Dirks \& Ferrin (2001) dalam "The role of trust in organisational setting" adalah bahwa kepercayaan akan menghasilkan efek berbeda seperti sikap yang lebih positif terhadap lembaga, tingginya tingkat kerjasama, dan perbaikan kinerja. Sejalan dengan prespektif Dirks \& Ferrin, "kepercayaan dan komitmen merupakan efek samping dari proses dan kebijakan yang dirancang untuk membuat hubungan yang memuaskan bagi level atas UNP dan level bawah UNP. Kondisi ini dapat diamati dari pola komunikasi yang lebih terbuka, tepat, dan jelas". Kepercayaan dapat disampaikan melalui komunikasi yang efektif melalui keterbukaan dan perhatian. Praktik komunikasi dalam organisasi UNP di masa depan diharapkan berpengaruh penting terhadap kepercayaan sivitas akademika UNP kepada kebijakan pimpinan UNP serta komitmen bersama sivitas akademika terhadap UNP.

Keempat, kemampuan lembaga dalam memotivasi sivitas tentang perubahan. Motivasi dalam konteks ini adalah dorongan yang menyebabkan seluruh sivitas akademika UNP untuk berperilaku sejalan dengan maksud WCU (Kroth, 2007). Komunikasi juga terbukti menjadi alat yang efektif untuk memotivasi dalam proses perubahan (Luecke, 2003). Kecukupan informasi yang disediakan oleh pimpinan UNP akan berkontribusi terhadap kepuasan kerja dosen dan karyawan, yang pada gilirannya akan mendorong partisipasi mahasiswa dan masyarakat di sekitar UNP untuk mendukung target WCU.

Kelima, kemampuan lembaga dalam membangun komitmen sivitas. Komitmen secara kontekstual terkait dengan seberapa besar aspirasi dan argumentasi yang berkembang di level mahasiswa, dosen, karyawan UNP. Secara konseptual, hal ini berhubungan dengan ruang kebebasan berpendapat mengenai kekhawatiran terhadap perubahan. Semakin besar opini yang berkembang dapat dimaknai sebagai seberapa besar keingintahuan, dan keingintahuan berhubungan dengan seberapa dalam komitmen dalam mencintai UNP. Di sisi lain, komitmen sivitas akademika UNP sangat tergantung pada pengetahuan dan pemahaman tentang isu-isu strategis dari perubahan yang dikehendaki oleh level pimpinan UNP. Dengan demikian, komunikasi harus dikelola dengan baik, karena komitmen dan dukungan berasal dari komunikasi yang dibangun oleh mahasiswa, dosen, dan karyawan serta masyarakat sekitar UNP dengan pimpinan UNP.

Keenam, kemampuan lembaga dalam membangun iklim partisipatif. Partisipasi dapat dimaknai sebagai taking part (ambil bagian), karena UNP adalah milik bersama seluruh sivitas, maka seluruh sivitas berkewajiban secara bersama untuk mengambil bagian dari persoalan yang patut diselesaikan untuk menuju target WCU. Partisipasi tentu tidak saja lahir secara alamiah, namun perlu pendekatan yang direkayasa agar seluruh merasa sebagai satu bagian. Keterbukaan dan pelibatan secara bersama dengan mendengarkan masukan dan argumentasi berdasar dari seluruh sivitas akademika UNP sejatinya adalah hal yang perlu bagi pimpinan UNP dalam pengambilan keputusan tentang perubahan. Penguatan fungsi kelembagaan organisasi mahasiswa dapat menciptakan iklim partisipatif ini secara perlahan, atau forum dengar pendapat yang diselenggarakan di seluruh lini dosen dan karyawan.

\section{Kesimpulan}

Peran komunikasi selama perubahan UNP menuju WCU sangat penting. Mahasiswa, dosen, dan karyawan serta masyarakat sekitar adalah sumberdaya utama perubahan UNP di masa depan, khususnya menjadi WCU. Untuk mendorong seluruh sivitas akademika UNP untuk mencapai target perubahan yang diinginkan, secara kelembagaan, UNP haruslah mampu mengatasi kekhawatiran dan masalah yang terkait dengan kebutuhan mahasiswa, dosen, karyawan dan masyarakat sekitar UNP. Kekhawtiran terhadap kegagalan dalam upaya mencapai perubahan harus dikurangi. Rasa kekeluargaan harus diciptakan, sehingga sivitas akademika UNP dapat secara langsung merasakan tanggung jawab yang harus dipenuhi. Target perubahan UNP menuju WCU merupakan keharusan bagi seluruh sivitas akademika UNP. Komunikasi berbasis keterbukaan yang telah dikembangkan perlu dirawat sebagai suatu praktek pendidikan bermatra informasional.

\section{Daftar Bacaan}

Beer, M., \& Nohria, N. (2000). Breaking the code of change. Boston: Harvard Business School Press.

Bennebroek-Gravenhorst, K., Elving, K., \& Werkman, R. (2006). Test and application of the 
communication and organizational change questionnaire. Paper presented at the annual meeting of the International Communication Association, Dresden, Germany, June.

Bibler, R. S. (1989). The Arthur Young management guide to mergers and acquisitions. New Jersey: Wiley.

De Ridder, J. (2003). Organisational communication and supportive employees. Human Resource Management Journal, 4(4), 1-10.

Difonzo, N., \& Bordia, P. (1998). A tale of two corporations: Managing uncertainty during organisational change. Human Resource Management, 37(3), 295-303.

Dirks, K. T., \& Ferrin, D. L. (2001). The role of trust in organisational setting. Organisational Science, 12(4), 450467.
Elving, W., \& Hansma, L. (2008). Leading organizational change: On the role of top management and supervisors in communicating organizational change. Paper presented at the annual meeting of the International Communication Association, Montreal, Quebec, May, 1-45.

Kroth, M. (2007). The manager as motivator. Westport: Praeger.

Luecke, R. (2003). Managing change and transition. Boston: Harvard Business School Press.

Zhang, H., \& N. C. Agarwal (2009). The mediating roles of organizational justice on the relationships between HR practices and workplace outcomes: An investigation in China. The International Journal of Human Resource Management, 20(3), 676-693. 